\title{
Changing trends in the microvascular reconstruction and oral rehabilitation following maxillary cancer
}

\author{
Simon N. Rogers ${ }^{1,4}(\mathbb{D}) \cdot$ Ashni Adatia $^{1} \cdot$ Stephanie Hackett ${ }^{1} \cdot$ Angela Boscarino $^{1} \cdot$ Anika Patel $^{1} \cdot$ Derek Lowe $^{3}$. \\ Christopher J. Butterworth ${ }^{1,2}$
}

Received: 24 December 2021 / Accepted: 17 January 2022 / Published online: 1 February 2022

(C) The Author(s) 2022

\begin{abstract}
Purpose The maxillectomy defect is complex and the best means to achieve optimal reconstruction, and dental rehabilitation is a source of debate. The refinements in zygomatic implant techniques have altered the means and speed by which rehabilitation can be achieved and has also influenced the choice regarding ideal flap reconstruction. The aim of this study is to report on how the method of reconstruction and oral rehabilitation of the maxilla has changed since 1994 in our Institution, and to reflect on case mix and survival.

Methods Consecutive head and neck oncology cases involving maxillary resections over a 27-year period between January 1994 and November 2020 were identified from hospital records and previous studies. Case note review focussed on clinical characteristics, reconstruction, prosthetic rehabilitation, and survival.

Results There were 186 patients and the tumour sites were: alveolus for 56\% (104), hard palate for 19\% (35), maxillary sinus for $18 \%$ (34) and nasal for $7 \%$ (13). 52\% (97) were Brown class 2 defects. Forty-five patients were managed by obturation and 78\% (142/183) had free tissue transfer. The main flaps used were radial (52), anterolateral thigh (27), DCIA (22), scapula (13) and fibula (11). There were significant changes over time regarding reconstruction type, use of primary implants, type of dental restoration, and length of hospital stay. Overall survival after 24 months was 64\% (SE 4\%) and after 60 months was $42 \%$ (SE $4 \%$ ).

Conclusion These data reflect a shift in the reconstruction of the maxillary defect afforded by the utilisation of zygomatic implants.
\end{abstract}

Keywords Maxillectomy $\cdot$ Free tissue transfer $\cdot$ Reconstruction $\cdot$ Oral rehabilitation · Zygomatic implants · ZIP flap

Simon N. Rogers

simon.rogers10@nhs.net

Ashni Adatia

ashni.adatia@nhs.scot

Stephanie Hackett

Stephanie.Hackett@liverpoolft.nhs.uk

Angela Boscarino

angela.boscarino@nhs.net

Anika Patel

anika.pate119@nhs.net

Derek Lowe

astraglobeltd@btconnect.com
Christopher J. Butterworth

c.butterworth@liv.ac.uk

1 Regional Maxillofacial Unit, Liverpool Head and Neck Centre, Liverpool University Hospital NHS Foundation Trust, Lower Lane, Liverpool, UK

2 Faculty of Health and Life Sciences, University of Liverpool, Liverpool, UK

3 Astraglobe Ltd, Congleton, Cheshire, England

4 Faculty of Health, Social Care and Medicine, Edge Hill University, Ormskirk L39 4QP, England 


\section{Introduction}

Oncological resection of the maxilla results in a complex defect which can be a challenge to optimally reconstruct and provide dental rehabilitation and function in the context of personalised treatment planning and outcomes. There are several reconstructive options including local tissue flaps, prosthetic obturation, the use of osseointegrated implants, as well as soft tissue and composite free tissue transfer [1,2]. Many factors influence the most appropriate reconstruction such as the extent of the defect, dental status, motivation of the patient for oral rehabilitation, comorbidity, institutional experience and clinician preferences. The complexity of the defect in part is reflected in the various classifications that have been previously advocated [3-9] and the options for reconstruction are epitomised by the different algorithms and techniques published over the years [3-5, 10-15]. The reconstruction of the defect might be influenced to a degree, by the relatively poor survival prognosis in those having maxillary resection compared to other head and neck cancer sites, notably oral cavity $[16,17]$. This leads to a concept of radical palliative surgery with curative intent, such that for those where cure is ultimately not possible there should ideally be a time of comparatively satisfactory function and quality of life associated with minimal treatment burden and necessity for further hospital procedures. In long-term survivors who are recurrence free, secondary oral rehabilitation adds another level of difficulty with the balance of risk versus benefit especially relevant for those who have had post-operative radiotherapy. In this group the risk of osteoradionecrosis and prosthetic failure versus improvement in appearance, chewing, speech and swallowing must be carefully considered [18]. Many patients do not complete full oral rehabilitation and cope and adapt to their outcome [19].

Given the complexity associated with the maxillary defect, the aim of this study is to report changes in the method of reconstruction and oral rehabilitation of the maxilla since 1994 in our Institution, and to reflect on case mix and survival. For the purpose of this study, there is an emphasis on oral rehabilitation; hence, the maxillary defect has focussed on those resections involving the maxillary alveolus, hard palate, maxillary sinus and nasal complex restricted to Classes 1 to 4 of the Brown classification [7].

\section{Methods}

Consecutive head and neck oncology cases involving maxillary resections over a 27 -year period between January 1994 and November 2020 at the Liverpool University
Foundation NHS Trust were identified from the hospital operating theatre database. The following theatre codes [20] were used to screened eligibility for possible maxillary resection; V06.9 unspecified excision of maxilla, V07.2 partial excision of bone of face, V07.1 extensive excision of bone of face and V07.8 other specified excision of bone of face. Hard palate and maxillary alveolus were considered as part of maxillary resection. Patients were excluded if maxillary surgery had been flagged up in the non-oncology setting, such as osteotomies, temporomandibular surgery, or trauma. Cases with a Brown's classification of 5 or 6 were also excluded as the focus of the sample were those defects suitable for oral rehabilitation. Datasets from previous research [21, 22] were also searched for cross reference and verified on the electronic hospital records to add cases not identified from the operating theatre database.

Patient data were collected from the electronic case notes, including outpatient clinical letters, multi-disciplinary entries and radiographs. Rehabilitation data were collected from the Liverpool University Dental Hospital Implant Database. Patient clinical and demographic characteristics included the American Society of Anaesthesiologists (ASA) grade [23] site and diagnosis of tumour, operation date, length of stay, Brown's classification of maxillary resection [7], pathological staging (pTNM) [24], type of flap used for reconstruction, oral rehabilitation, post-operative radio/chemotherapy and survival time.

\section{Ethical approval}

The data were collected as part of the clinical audit process and this study was approved by Liverpool University Hospital NHS Foundation Trust Audit Department (CAMS reference 10074).

\section{Statistical analysis}

Fisher's exact test was used to compare categorical data between patient subgroups and the Kruskal-Wallis test was used to compare numerical data. The three time periods analysed were tertiles derived from the number of patients each year over the whole time period. Survival statistics were calculated using the Kaplan-Meier method and the log-rank test. SPSS v25 and STATA v13 were used for the analyses. Given the number of tests, statistical significance was interpreted at the $1 \%$ level. A small number of patients were operated on more than once during the study period ( 6 twice and 1 thrice) and these subsequent operations were excluded from the statistical analysis. 


\section{Results}

The study sample comprised 186 patients with Brown's 1-4 maxillary resection seen between 1994 and 2020 . Median (IQR) age at primary tumour diagnosis was 69 (59-77) years and 51\% (94) were male. Male patients tended to be younger with 23\% (22/94) of men aged $\geq 75$ years compared to $45 \%$ (41/92) of women. Primary tumour site was alveolus for 56\% (104), hard palate for $19 \%$ (35), maxillary sinus for $18 \%$ (34) and nasal for $7 \%(13)$. Most $(86 \%, 160)$ tumours were diagnosed as SCC, $76 \%$ (130/172) were pT stage $3-4$ and $24 \%$ (42/172) were $\mathrm{pN}$ positive, with $77 \%$ (133/172) being overall stage 3-4. Brown's classification was level 1 for $26 \%$ (48), level 2 for 52\% (97), level 3 for $7 \%$ (13) and level 4 for $15 \%$ (28). ASA was grade 3-4 for 20\% (36/179), with 33 grade 3 and 3 grade 4 . Surgery alone was used for $40 \%$ (75) while for $60 \%$ (111) treatment comprised surgery and either radiotherapy, chemotherapy or both. Reconstructive flaps were used for $76 \%$ (142), comprising 81 soft flaps and 61 involving hard tissue composite flaps. The main free flaps used were radial (52), anterolateral (27), DCIA (23), scapula (14) and fibula (11). Median (IQR) length of hospital stay (LOS) was 10 (7-16) days.

A fuller breakdown of patient casemix is shown in Table 1, with results also stratified by time period (tertiles), i.e. for 1994-2009, 2010-2015 and 2016-2020. There were significant changes over time in regard to flap reconstruction, LOS, ASA grade and diagnosis. The percentage having flap reconstruction rose from $72 \%$ (1994-2009) and 63\% (2010-2015) to 91\% (2016-2020); the percentages having radial flap reconstructions were $19 \%, 11 \%$ and $51 \%$ while the percentages having DCIA flaps were $17 \%, 17 \%$ and $3 \%$. Unsurprisingly the LOS fell over the whole study period, from a median of 15 days (1994-2009) to 10 days (2010-2015) and 9 days (2016-2020). The percentages with ASA grades 3-4 were similar over the 3 time periods, the differences being in the mix of grades 1 and 2 with $18 \%$ grade 1's for 1994-2009, $7 \%$ for $2010-2015$ and $35 \%$ for 2016-2020. All but one of the non-SCC tumours in the study sample were after 2010.

No oral rehabilitation was provided for $43 \%$ (78/183), while implant supported prostheses were provided for $36 \%(65 / 183)$, non-implant prostheses for $31 \%(39 / 183)$ and both types for 1 patient. There were significant changes over time (Table 2) with implant prostheses provision rising from $22 \%$ for $1994-2009$ and $29 \%$ for 2010-2015 to $52 \%$ for 2016-2020; correspondingly, the use of non-implant support declined from 39 to $18 \%$ and $12 \%$, respectively. Most implant support was by bridge or retained obturator while most non-Implant support was by obturator. Over time, there was a notable rise after 2015 in the use of a zygomatic implant supported implant bridge and a reduction in other forms of implant support; there was also a steady decline across the study period in the use of non-implant obturator support. Most (91\%) implants before 2010 were performed after the primary surgery, while most after 2010 were performed at the same time as initial surgery (67\% for $2010-2015$ and $92 \%$ for 2016-2020). Patients significantly less likely to have rehabilitation (Table 3) were those with high-level Browns classification (63\% level 3-4 vs 37\% level 1-2), those treated by surgery with radiotherapy and chemotherapy (76\%) compared with $33 \%$ for surgery alone and $40 \%$ for surgery with either radiotherapy or chemotherapy but not both, those with flap reconstruction (60\% composite, $43 \%$ soft, $18 \%$ no flap), younger patients $(57 \%$ if $<65$ years, $40 \%$ if $65-74$ years and $29 \%$ if $\geq 75$ years), and those with longer LOS (28\% if $\leq 7$ days, $43 \%$ if $8-14$ days and $57 \%$ if $\geq 15$ days). For those that had rehabilitation, there were no notable associations amongst the casemix variables with whether the rehabilitation was implant or non-implant supported (Table 3).

The use of reconstructive flaps ( $76 \%$ overall) was associated significantly with many of the casemix variables (Table 4). Flap use was higher for patients with maxillary sinus tumours, more advanced tumour staging, high-level Browns classification, treated with radiotherapy and/or chemotherapy in addition to the surgery, and for patients with longer LOS. For those that had flap reconstructions, the most notable indicators towards having composite rather than soft flaps were younger age (62\% 34/55 for $<65$ years, $31 \% 27 / 87$ for $\geq 65$ years), more advanced tumour staging (50\% 58/117 for late 3-4 overall stage, $5 \%$ (1/21) for earlier staging), involvement of radiotherapy and/or chemotherapy treatment (52\% 53/101 with, 20\% $8 / 41$ without) and longer LOS (47\% 51/108 $\geq 8$ days, $17 \% 4 / 23 \leq 7$ days). For those without a flap, the median (IQR) LOS was 3 (1-7) days, compared to 11 (7-18) days with soft flap and 14 (10-17) days with composite flap, Kruskal-Wallis test $P<0.001$ comparing all 3 groups and $P=0.02$ (borderline sign) comparing soft flap with composite flap.

Overall survival after 24 months was 64\% (SE 4\%) and after 60 months was $42 \%$ (SE 4\%). Casemix factors most strongly associated with better survival (Table 5) were less advanced tumour staging, rehabilitation support and a shorter LOS. Survival curves by pTN staging and by Browns classification are shown in Figs. 1 and 2 respectively. The overall recurrence rate was $40 \%$ (74/186), with little difference noted when analysed by Browns classification (Level 1: 40\%, 19/48, Level 2: 40\%, 39/97, Level 3: $38 \%, 5 / 13$, Level 4: 39\%, 11/28). 
Table 1 Casemix, 1994-2020

\begin{tabular}{|c|c|c|c|c|c|c|c|c|c|}
\hline \multirow[b]{3}{*}{ All patients } & \multicolumn{2}{|l|}{ 1994-2009 } & \multicolumn{2}{|l|}{ 2010-2015 } & \multicolumn{2}{|l|}{ 2016-2020 } & \multirow[t]{3}{*}{$P$ value* } & \multicolumn{2}{|l|}{ Total } \\
\hline & $N$ & $\%$ & $N$ & $\%$ & $N$ & $\%$ & & $N$ & $\%$ \\
\hline & 54 & 100 & 63 & 100 & 69 & 100 & & 186 & 100 \\
\hline \multicolumn{10}{|l|}{ Gender } \\
\hline Male & 22 & 41 & 35 & 56 & 37 & 54 & \multirow[t]{2}{*}{0.24} & 94 & 51 \\
\hline Female & 32 & 59 & 28 & 44 & 32 & 46 & & 92 & 49 \\
\hline \multicolumn{10}{|l|}{ Age (operation) } \\
\hline Median (IQR) years & \multicolumn{2}{|l|}{$70(58-78)$} & \multicolumn{2}{|l|}{$68(56-78)$} & \multicolumn{2}{|l|}{$71(63-76)$} & 0.62 & \multicolumn{2}{|l|}{$69(59-77)$} \\
\hline \multicolumn{10}{|l|}{ Site } \\
\hline Alveolus & 27 & 50 & 32 & 51 & 45 & 65 & \multirow[t]{4}{*}{0.06} & 104 & 56 \\
\hline Hard palate & 14 & 26 & 16 & 25 & 5 & 7 & & 35 & 19 \\
\hline Max sinus & 11 & 20 & 10 & 16 & 13 & 19 & & 34 & 18 \\
\hline Nasal & 2 & 4 & 5 & 8 & 6 & 9 & & 13 & 7 \\
\hline \multicolumn{10}{|l|}{ Overall P stage } \\
\hline Early (1-2) & 7 & 14 & 14 & 25 & 18 & 26 & \multirow[t]{3}{*}{0.26} & 39 & 23 \\
\hline Late $(3-4)$ & 42 & 86 & 41 & 75 & 50 & 74 & & 133 & 77 \\
\hline NK & 5 & & 8 & & 1 & & & 14 & \\
\hline \multicolumn{10}{|l|}{ Diagnosis } \\
\hline $\mathrm{SCC}$ & 53 & 98 & 51 & 81 & 56 & 81 & \multirow[t]{2}{*}{0.003} & 160 & 86 \\
\hline Non-SCC *** & 1 & 2 & 12 & 19 & 13 & 19 & & 26 & 14 \\
\hline Browns classification & & & & & & & & & \\
\hline 1 & 10 & 19 & 25 & 40 & 13 & 19 & 0.04 & 48 & 26 \\
\hline 2 & 32 & 59 & 23 & 37 & 42 & 61 & & 97 & 52 \\
\hline 3 & 2 & 4 & 6 & 10 & 5 & 7 & & 13 & 7 \\
\hline 4 & 10 & 19 & 9 & 14 & 9 & 13 & & 28 & 15 \\
\hline Low level 1-2 & 42 & 78 & 48 & 76 & 55 & 80 & 0.88 & 145 & 78 \\
\hline High level 3-4 & 12 & 22 & 15 & 24 & 14 & 20 & & 41 & 22 \\
\hline ASA & & & & & & & & & \\
\hline 1 & 9 & 18 & 4 & 7 & 24 & 35 & 0.002 & 37 & 21 \\
\hline 2 & 30 & 61 & 43 & 70 & 33 & 48 & & 106 & 59 \\
\hline $3-4$ & 10 & 20 & 14 & 23 & 12 & 17 & & 36 & 20 \\
\hline NK & 5 & & 2 & & - & & & 7 & \\
\hline Treatment & & & & & & & & & \\
\hline Surgery (S) alone & 22 & 41 & 30 & 48 & 23 & 33 & 0.02 & 75 & 40 \\
\hline S and RT primary & - & - & - & - & 1 & 1 & & 1 & 1 \\
\hline S and RT post-op & 30 & 56 & 19 & 30 & 36 & 52 & & 85 & 46 \\
\hline $\mathrm{S}$ and $\mathrm{CT}$ & - & - & 3 & 5 & 1 & 1 & & 4 & 2 \\
\hline S and RT post-op and CT & 2 & 4 & 11 & 17 & 8 & 12 & & 21 & 11 \\
\hline Surgery (S) alone & 22 & 41 & 30 & 48 & 23 & 33 & 0.26 & 75 & 40 \\
\hline $\mathrm{S}$ and (RT or CT or RTCT) & 32 & 59 & 33 & 52 & 46 & 67 & & 111 & 60 \\
\hline Flap & & & & & & & & & \\
\hline No & 15 & 28 & 23 & 37 & 6 & 9 & $<0.001$ & 44 & 24 \\
\hline Soft & 13 & 24 & 24 & 38 & 44 & 64 & & 81 & 44 \\
\hline Composite**** & 26 & 48 & 16 & 25 & 19 & 28 & & 61 & 33 \\
\hline Flap detail & & & & & & & & & \\
\hline None & 15 & 28 & 23 & 37 & 6 & 9 & - & 44 & 24 \\
\hline Radial & 10 & 19 & 7 & 11 & 35 & 51 & & 52 & 28 \\
\hline ALT & 6 & 11 & 11 & 17 & 10 & 14 & & 27 & 15 \\
\hline Lat dorsi & 3 & 6 & 2 & 3 & 3 & 4 & & 8 & 4 \\
\hline Rectus abdom & 1 & 2 & 4 & 6 & - & - & & 5 & 3 \\
\hline
\end{tabular}


Table 1 (continued)

\begin{tabular}{|c|c|c|c|c|c|c|c|c|c|}
\hline \multirow[b]{3}{*}{ All patients } & \multicolumn{2}{|c|}{ 1994-2009 } & \multicolumn{2}{|c|}{ 2010-2015 } & \multicolumn{2}{|c|}{ 2016-2020 } & \multirow[t]{2}{*}{$P$ value* } & \multicolumn{2}{|l|}{ Total } \\
\hline & $N$ & $\%$ & $N$ & $\%$ & $N$ & $\%$ & & $N$ & $\%$ \\
\hline & 54 & 100 & 63 & 100 & 69 & 100 & & 186 & 100 \\
\hline Buccal fat pad & - & - & 1 & 2 & 1 & 1 & & 2 & 1 \\
\hline DCIA & 9 & 17 & 11 & 17 & 2 & 3 & & 22 & 12 \\
\hline Scapula & 5 & 9 & 1 & 2 & 7 & 10 & & 13 & 7 \\
\hline Fibula & 4 & 7 & 2 & 3 & 5 & 7 & & 11 & 6 \\
\hline Lat dorsi and DCIA & 1 & 2 & - & - & - & - & & 1 & 1 \\
\hline Lat dorsi and scap & - & - & 1 & 2 & - & - & & 1 & 1 \\
\hline \multicolumn{10}{|l|}{ LOS (days) } \\
\hline$\leq 7$ & 8 & 18 & 20 & 36 & 26 & 38 & $<0.001$ & 54 & 32 \\
\hline $8-14$ & 11 & 24 & 20 & 36 & 32 & 46 & & 63 & 37 \\
\hline$\geq 15$ & 26 & 58 & 15 & 27 & 11 & 16 & & 52 & 31 \\
\hline NK & 9 & & 8 & & - & & & 17 & \\
\hline Median (IQR) & $15(9-22)$ & & $10(4-15)$ & & $9(7-13)$ & & 0.001 & $10(7-16)$ & \\
\hline
\end{tabular}

$R T$ radiotherapy, $C T$ chemotherapy

*Fishers exact test, apart from use of Kruskal-Wallis test for Age and LOS. NK (not known) groups excluded

**24 of the $130 \mathrm{pN} 0$ were based on clinical grounds only—no neck access with 11 of 41,3 of 39 and 10 of 50 across the time periods

***Across time periods the 26 non-SCC comprised: acinic cell $(0,0,1)$, adenocarcinoma $(0,3,6)$, ameloblastoma $(0,4,0)$, melanoma $(0,2,2)$, Merkel cell $(0,1,0)$,mucoepidermoid $(1,1,0)$, non-keratinising Schneiderian $(0,0,1)$, Sarcoma $(0,0,1)$, Sinonasal undifferentiated $(0,1,0)$ verrucous $(0,0,2)$

****For 2 patients, both soft and composite flaps were used (Lat dorsi and scapula, Lat dorsi and DCIA), coded here under composite

\section{Discussion}

Controversy remains regarding the most appropriate reconstruction and oral rehabilitation for the post-oncology maxillary defect. As treatments become more refined over time, there is merit in reflecting back over several decades as this allows an opportunity to report changes in treatment strategies, survival and rehabilitation outcomes. Although the data are limited to one Institution, it represents a substantial series collated over many years. It is accepted that as a retrospective casenote review, there are various other aspects that are important which it has not been possible to report in this study, such as post-operative complications, donor site morbidity and health-related quality of life (HRQOL).

In our sample, Brown's classification 1 and 2 predominate (78\% of cases). In this relatively low-level defect, the main component of dysfunction in form and function is related to the teeth and the surgically created fistula between the oral cavity and the nose/maxillary sinus. The importance of oral function to HRQOL is well recognised [25] and issues of chewing, dental appearance, teeth, speech are amongst the commonest concerns [26]. Oral rehabilitation has a critical role in promoting optimal patient reported outcomes [25, 27]. The pathology, whether benign or malignant is an important consideration in terms of resection and reconstruction. In this case series, the focus has been on cancer and unsurprisingly the majority were squamous cell carcinoma. Over the time period of this study, there has been centralisation of the service [28] and this might account for variations in pathology where some earlier cases would have been managed in the surrounding hospitals and not referred. Resection for benign disease such as pleomorphic adenoma tends to be less destructive in relation to achieving margins and post-operative radiotherapy can be avoided. In our oncology cohort, over half of patients received post-operative radiotherapy and this is an important consideration in respect to treatment burden, and the scope for successful primary or secondary oral rehabilitation. Another essential aspect is the tumour stage and hence prognosis. Three quarters were pathological stage 3 or 4 and a quarter had cervical lymph node metastases. With advanced stage disease, the rates of failure over the first 2 years increase and there is a management imperative to help enable the patient to achieve the best possible HRQOL in the time remaining. In addition, specifically in this group, the burden of additional treatments should be minimised, for example, the need for multiple hospital visits for oral rehabilitation, further surgery, and modifications to the prosthesis. Ideally, there needs to be coordinated multidisciplinary clinical review. 
4118

European Archives of Oto-Rhino-Laryngology (2022) 279:4113-4126

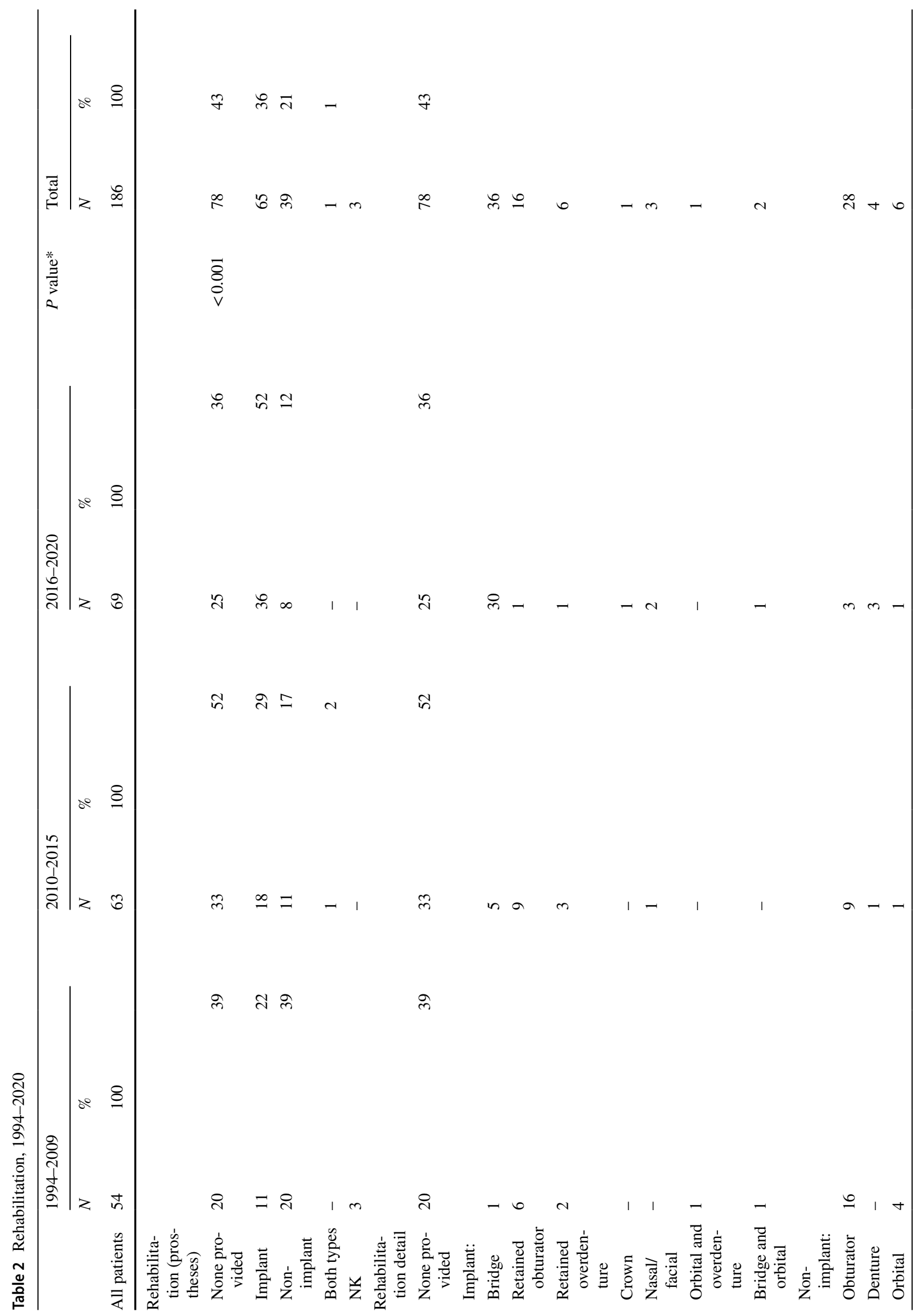

Springer 
European Archives of Oto-Rhino-Laryngology (2022) 279:4113-4126

4119

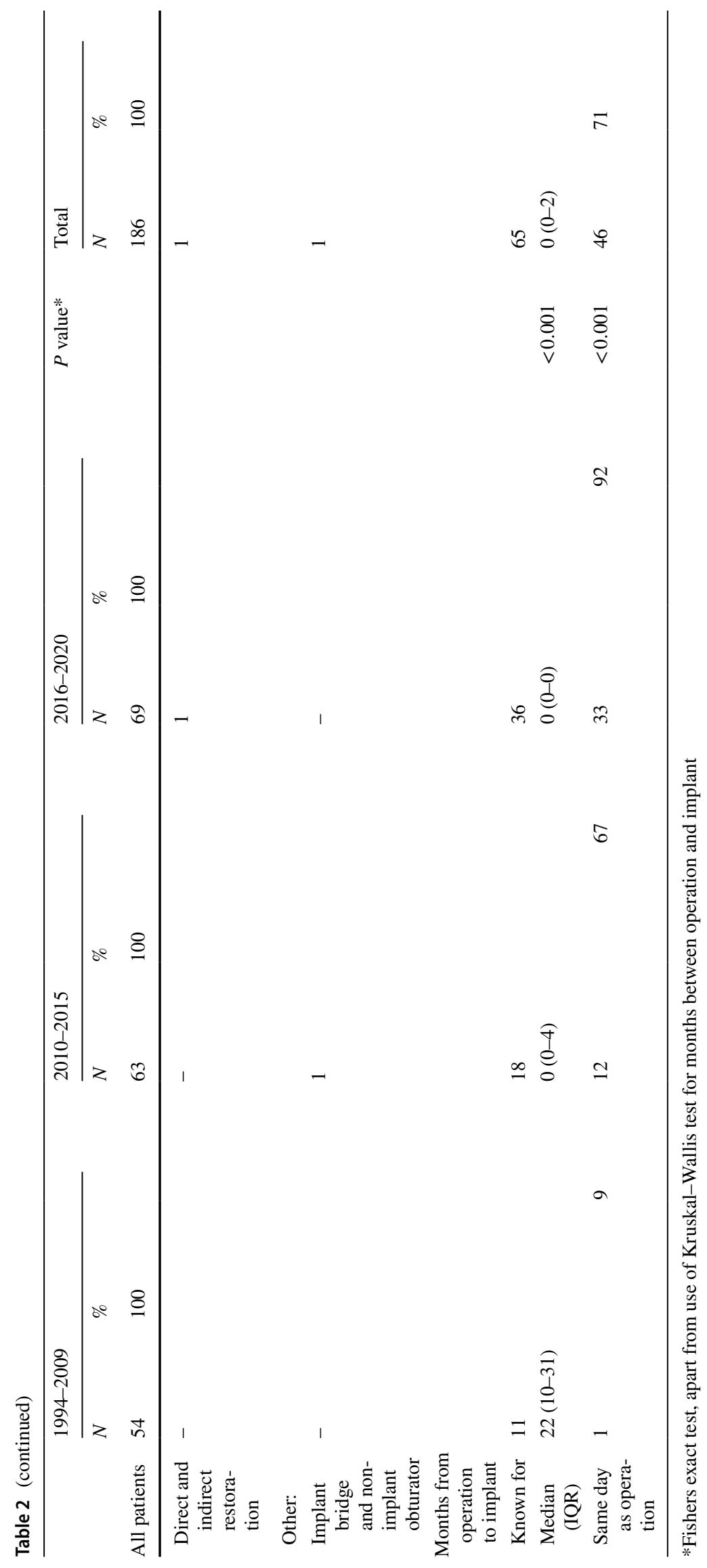

型 Springer 
Table 3 Casemix and rehabilitation

\begin{tabular}{|c|c|c|c|c|c|c|c|c|c|}
\hline \multirow[b]{3}{*}{ All patients } & \multirow{3}{*}{$\begin{array}{l}\text { Total } \\
183\end{array}$} & \multicolumn{2}{|c|}{ No rehab } & \multicolumn{2}{|c|}{$\begin{array}{l}\text { Implant } \\
\text { rehab** }^{*}\end{array}$} & \multicolumn{2}{|c|}{$\begin{array}{l}\text { Non- } \\
\text { implant } \\
\text { rehab }\end{array}$} & \multirow[t]{3}{*}{$\begin{array}{l}P \text { value* } \\
\text { (no rehab vs yes) }\end{array}$} & \multirow[t]{3}{*}{$\begin{array}{l}P \text { value* } \\
\text { Implant vs non- } \\
\text { implant (if rehab) }\end{array}$} \\
\hline & & $N$ & $\%$ & $N$ & $\%$ & $N$ & $\%$ & & \\
\hline & & 78 & 43 & 66 & 36 & 39 & 21 & & \\
\hline \multicolumn{10}{|l|}{ Gender } \\
\hline Male & 91 & 48 & 53 & 28 & 31 & 15 & 16 & 0.007 & 0.84 \\
\hline Female & 92 & 30 & 33 & 38 & 41 & 24 & 26 & & \\
\hline \multicolumn{10}{|l|}{ Age (operation) } \\
\hline$<65$ & 68 & 39 & 57 & 19 & 28 & 10 & 15 & 0.004 & 0.19 \\
\hline $65-74$ & 52 & 21 & 40 & 23 & 44 & 8 & 15 & & \\
\hline$\geq 75$ & 63 & 18 & 29 & 24 & 38 & 21 & 33 & & \\
\hline \multicolumn{10}{|l|}{ Site } \\
\hline Alveolus & 102 & 40 & 39 & 38 & 37 & 24 & 24 & 0.12 & 0.12 \\
\hline Hard palate & 35 & 12 & 34 & 17 & 49 & 6 & 17 & & \\
\hline Max sinus & 33 & 20 & 61 & 5 & 15 & 8 & 24 & & \\
\hline Nasal & 13 & 6 & 46 & 6 & 46 & 1 & 8 & & \\
\hline \multicolumn{10}{|l|}{ Overall P stage } \\
\hline Early (1-2) & 39 & 12 & 31 & 16 & 41 & 11 & 28 & 0.07 & 0.64 \\
\hline Late (3-4) & 130 & 62 & 48 & 45 & 35 & 23 & 18 & & \\
\hline NK & 14 & 4 & & 5 & & 5 & & & \\
\hline \multicolumn{10}{|l|}{ Diagnosis } \\
\hline $\mathrm{SCC}$ & 157 & 68 & 43 & 57 & 36 & 32 & 20 & 0.68 & 0.58 \\
\hline Not SCC & 26 & 10 & 38 & 9 & 35 & 7 & 27 & & \\
\hline \multicolumn{10}{|l|}{ Browns classification } \\
\hline 1 & 47 & 17 & 36 & 16 & 34 & 14 & 30 & 0.02 & 0.02 \\
\hline 2 & 96 & 36 & 38 & 43 & 45 & 17 & 18 & & \\
\hline 3 & 13 & 10 & 77 & 2 & 15 & 1 & 8 & & \\
\hline 4 & 27 & 15 & 56 & 5 & 19 & 7 & 26 & & \\
\hline Low level 1-2 & 143 & 53 & 37 & 59 & 41 & 31 & 22 & 0.006 & 0.10 \\
\hline High level 3-4 & 40 & 25 & 63 & 7 & 18 & 8 & 20 & & \\
\hline \multicolumn{10}{|l|}{ ASA } \\
\hline 1 & 35 & 20 & 57 & 12 & 34 & 3 & 9 & 0.13 & 0.36 \\
\hline 2 & 106 & 40 & 38 & 39 & 37 & 27 & 25 & & \\
\hline $3-4$ & 35 & 14 & 40 & 13 & 37 & 8 & 23 & & \\
\hline NK & 7 & 4 & & 2 & & 1 & & & \\
\hline \multicolumn{10}{|l|}{ Treatment } \\
\hline Surgery $(\mathrm{S})$ alone & 75 & 25 & 33 & 28 & 37 & 22 & 29 & $<0.001$ & 0.14 \\
\hline $\mathrm{S}$ and RT primary & 1 & 1 & 100 & - & & - & & & \\
\hline S and RT post-op & 82 & 32 & 39 & 33 & 40 & 17 & 21 & & \\
\hline $\mathrm{S}$ and $\mathrm{CT}$ & 4 & 4 & 100 & - & & - & & & \\
\hline $\mathrm{S}$ and RT post-op and CT & 21 & 16 & 76 & 5 & 24 & - & & & \\
\hline Surgery $(\mathrm{S})$ alone & 75 & 25 & 33 & 28 & 37 & 22 & 29 & 0.05 & 0.23 \\
\hline $\mathrm{S}$ and (RT or CT or RTCT) & 108 & 53 & 49 & 38 & 35 & 17 & 16 & & \\
\hline \multicolumn{10}{|l|}{ Flap } \\
\hline None & 44 & 8 & 18 & 17 & 39 & 19 & 43 & $<0.001$ & 0.05 \\
\hline Soft & 81 & 35 & 43 & 34 & 42 & 12 & 15 & & \\
\hline Composite & 58 & 35 & 60 & 15 & 26 & 8 & 14 & & \\
\hline \multicolumn{10}{|l|}{ LOS (days) } \\
\hline$\leq 7$ & 54 & 15 & 28 & 23 & 43 & 16 & 30 & 0.01 & 0.02 \\
\hline $8-14$ & 63 & 27 & 43 & 29 & 46 & 7 & 11 & & \\
\hline$\geq 15$ & 49 & 28 & 57 & 10 & 20 & 11 & 22 & & \\
\hline
\end{tabular}


Table 3 (continued)

\begin{tabular}{llllllllll}
\hline & Total & No rehab & $\begin{array}{l}\text { Implant } \\
\text { rehab** }\end{array}$ & & & & & &
\end{tabular}

The series presented demonstrates that there is a definite place for obturation. Of the 45 patients, around onethird were implant retained and the remainder were managed without implants. In terms of the preferred methods of reconstruction, there has been a notable change over time. The vast majority of patients now have microvascular free tissue transfer. Furthermore, there has been less reliance on composite flaps to restore the defect with around half in last 5 years having radial free flaps. This has been accompanied by a reduction in hospital length of stay. The main driver for this change is the more frequent use of remotely anchored zygomatic implants to support the prosthesis [29-33]. With this technique, there is less reliance on bone transfer and an increasing focus on primary placement of zygomatic implants at the time of surgery. In terms of soft tissue, both the radial and the anterolateral thigh (ALT) free flaps have long pedicle lengths and this facilitates the ease of anastomosis in the neck. However, the ALT can be a bit too bulky for zygomatic implant perforation and subsequent fitting of the suprastructure. Despite the significant challenges, the ZIP flap technique provides full dental rehabilitation within 30 days of surgery and prior to radiotherapy if this is required, with excellent published patient reported outcomes [33]. There is a need for a bony free flap in the higher level maxillectomy defects [3], however, the Brown 3 and 4 defects are less common. Another factor which has influenced the change in practice is the recognition that in those patients in the past with relatively low-level defects and bony flap, the bone tended not to be used for oral rehabilitation and was not critical for restoration of facial profile. In addition, there has been concern regarding the placement of secondary implants in the irradiated field. Although optimal rehabilitation might not be achieved without the use of implant retention, their placement carries the risk of implant failure and osteoradionecrosis, and might confer only modest improvements in function and HRQOL $[25,32]$. Another factor that limits delayed oral rehabilitation is that a proportion develops loco-regional failure and are not surviving after 2 years $[17,34-36]$. It is encouraging that $64 \%$ in this cohort were alive after 24 months and $42 \%$ after 60 months. Tumour pathology is the main factor associated with survival factor but perhaps in a larger future sample it might be possible to tease out the relative risk of avoiding post-operative radiotherapy (de-escalation) in the low-level maxillectomy and report the benefit of this in terms of trade-off in treatment burden, side-effects and HRQOL.

There is still a place for composite free tissue alone, especially in the extensive resections, to provide adequate function and HROQOL, accepting that formal oral rehabilitation will not be achieved [19]. However, the emergence of zygomatic implants informs the previous algorithms for maxillary reconstruction [3-5, 10-15]. It is accepted that the utilisation of this approach relies on the experience and expertise of the clinician placing the implants and the maxillofacial prosthodontic team providing the prosthesis. This resource is available in our Institution and has allowed this approach to be routinely considered. Some units might wish to use computer-derived models and guides to assist with the placement of bone and implants at the time of primary surgery [37-39]. Whatever techniques are used to facilitate the accurate placement of the implants the imperative remains for these to be used for rehabilitation without undue delay.

In conclusion, there has been a change in the pattern on reconstruction of the maxillary defect over the last $3 \mathrm{dec}$ ades. The majority now have free tissue reconstruction and there is a stronger emphasis on the incorporation of primary zygomatic implants and oral rehabilitation via early-loaded implant supported fixed bridge reconstruction. Although the prognosis is still relatively poor, early meaningful rehabilitation is feasible and the combination of zygomatic implants has changed the paradigm as to the optimal microvascular reconstruction. 
Table 4 Casemix and type of flap

\begin{tabular}{|c|c|c|c|c|c|c|c|c|c|}
\hline \multirow[b]{3}{*}{ All patients } & \multirow{3}{*}{$\begin{array}{l}\text { Total } \\
186\end{array}$} & \multicolumn{2}{|c|}{ No flap } & \multicolumn{2}{|c|}{ Soft flap } & \multicolumn{2}{|c|}{ Composite flap } & \multirow{3}{*}{$\begin{array}{l}P \text { value* } \\
\text { (no flap vs yes) }\end{array}$} & \multirow{3}{*}{$\begin{array}{l}P \text { value* } \\
\text { Soft vs composite) } \\
\text { (if flap) }\end{array}$} \\
\hline & & $N$ & $\%$ & $N$ & $\%$ & $N$ & $\%$ & & \\
\hline & & 44 & 24 & 81 & 44 & 61 & 33 & & \\
\hline \multicolumn{10}{|l|}{ Gender } \\
\hline Male & 94 & 15 & 16 & 38 & 40 & 41 & 44 & \multirow[t]{2}{*}{0.02} & \multirow[t]{2}{*}{0.02} \\
\hline Female & 92 & 29 & 32 & 43 & 47 & 20 & 22 & & \\
\hline \multicolumn{10}{|l|}{ Age (operation) } \\
\hline$<65$ & 68 & 13 & 19 & 21 & 31 & 34 & 50 & \multirow[t]{3}{*}{0.10} & \multirow[t]{3}{*}{0.001} \\
\hline $65-74$ & 55 & 10 & 18 & 30 & 55 & 15 & 27 & & \\
\hline$\geq 75$ & 63 & 21 & 33 & 30 & 48 & 12 & 19 & & \\
\hline \multicolumn{10}{|l|}{ Site } \\
\hline Alveolus & 104 & 29 & 28 & 46 & 44 & 29 & 28 & \multirow[t]{4}{*}{$<0.001$} & \multirow[t]{4}{*}{0.28} \\
\hline Hard palate & 35 & 12 & 34 & 14 & 40 & 9 & 26 & & \\
\hline Max sinus & 34 & - & - & 18 & 53 & 16 & 47 & & \\
\hline Nasal & 13 & 3 & 23 & 3 & 23 & 7 & 54 & & \\
\hline \multicolumn{10}{|l|}{ Overall P stage } \\
\hline Early (1-2) & 39 & 18 & 46 & 20 & 51 & 1 & 3 & \multirow[t]{3}{*}{$<0.001$} & \multirow[t]{3}{*}{$<0.001$} \\
\hline Late (3-4) & 133 & 16 & 12 & 59 & 44 & 58 & 44 & & \\
\hline NK & 14 & 10 & & 2 & & 2 & & & \\
\hline \multicolumn{10}{|l|}{ Diagnosis } \\
\hline SCC & 160 & 34 & 21 & 71 & 44 & 55 & 34 & \multirow[t]{2}{*}{0.08} & 0.79 \\
\hline Not SCC & 26 & 10 & 38 & 10 & 38 & 6 & 23 & & \\
\hline Browns classification & & & & & & & & & \\
\hline 1 & 48 & 25 & 52 & 17 & 35 & 6 & 13 & $<0.001$ & 0.05 \\
\hline 2 & 97 & 19 & 20 & 47 & 48 & 31 & 32 & & \\
\hline 3 & 13 & - & - & 4 & 31 & 9 & 69 & & \\
\hline 4 & 28 & - & - & 13 & 46 & 15 & 54 & & \\
\hline Low level 1-2 & 145 & 44 & 30 & 64 & 44 & 37 & 26 & $<0.001$ & 0.02 \\
\hline High level 3-4 & 41 & - & - & 17 & 41 & 24 & 59 & & \\
\hline ASA & & & & & & & & & \\
\hline 1 & 37 & 3 & 8 & 20 & 54 & 14 & 38 & 0.03 & 0.89 \\
\hline 2 & 106 & 29 & 27 & 43 & 41 & 34 & 32 & & \\
\hline $3-4$ & 36 & 10 & 28 & 16 & 44 & 10 & 28 & & \\
\hline NK & 7 & 2 & & 2 & & 3 & & & \\
\hline Treatment & & & & & & & & & \\
\hline Surgery (S) alone & 75 & 34 & 45 & 33 & 44 & 8 & 11 & $<0.001$ & 0.002 \\
\hline S and RT primary & 1 & - & - & - & - & 1 & 100 & & \\
\hline $\mathrm{S}$ and RT post-op & 85 & 9 & 11 & 37 & 44 & 39 & 46 & & \\
\hline $\mathrm{S}$ and $\mathrm{CT}$ & 4 & - & - & 2 & 50 & 2 & 50 & & \\
\hline S and RT post-op and CT & 21 & 1 & 5 & 9 & 43 & 11 & 52 & & \\
\hline Surgery $(\mathrm{S})$ alone & 75 & 34 & 45 & 33 & 44 & 8 & 11 & $<0.001$ & $<0.001$ \\
\hline $\mathrm{S}$ and (RT or CT or RTCT) & 111 & 10 & 9 & 48 & 43 & 53 & 48 & & \\
\hline LOS (days) & & & & & & & & & \\
\hline$\leq 7$ & 54 & 31 & 57 & 19 & 35 & 4 & 7 & $<0.001$ & 0.02 \\
\hline $8-14$ & 63 & 5 & 8 & 33 & 52 & 25 & 40 & & \\
\hline$\geq 15$ & 52 & 2 & 4 & 24 & 46 & 26 & 50 & & \\
\hline $\mathrm{NK}$ & 17 & 6 & & 5 & & 6 & & & \\
\hline
\end{tabular}

$R T$ radiotherapy, $C T$ chemotherapy

*Fishers exact test, excluding NK (not known) where applicable

**24 of the $130 \mathrm{pN} 0$ were based on clinical grounds only-no neck access with 12 of 44,7 of 81 and 5 of 61 across the three groups 
Table 5 Kaplan-Meier survival by casemix and rehabilitation

\begin{tabular}{|c|c|c|c|c|c|c|c|}
\hline All patients & $\begin{array}{l}\text { Known for } \\
183\end{array}$ & $\begin{array}{l}12 \text { months } \\
79 \text { (3) }\end{array}$ & $\begin{array}{l}24 \text { months } \\
64 \text { (4) }\end{array}$ & $\begin{array}{l}36 \text { months } \\
56(4)\end{array}$ & $\begin{array}{l}48 \text { month } \\
46(4)\end{array}$ & $\begin{array}{l}60 \text { months } \\
42 \text { (4) }\end{array}$ & $P$ value* \\
\hline \multicolumn{8}{|l|}{ Time period } \\
\hline 1994-2009 & 54 & $81(5)$ & $64(7)$ & $57(7)$ & $47(7)$ & $41(7)$ & 0.71 \\
\hline 2010-2015 & 60 & $70(6)$ & $63(6)$ & $58(7)$ & $46(7)$ & $43(7)$ & \\
\hline 2016-2020 & 69 & $85(5)$ & $61(7)$ & $52(8)$ & $44(9)$ & NA & \\
\hline \multicolumn{8}{|l|}{ Gender } \\
\hline Male & 93 & $76(5)$ & $64(5)$ & $58(5)$ & $46(6)$ & $40(6)$ & 0.88 \\
\hline Female & 90 & $81(4)$ & $63(5)$ & $55(6)$ & $47(6)$ & $43(6)$ & \\
\hline \multicolumn{8}{|l|}{ Age } \\
\hline$<65$ & 67 & $77(5)$ & $65(6)$ & $62(6)$ & $53(7)$ & $53(7)$ & 0.04 \\
\hline $65-74$ & 54 & $81(5)$ & $68(7)$ & $60(7)$ & $51(8)$ & $36(8)$ & \\
\hline$\geq 75$ & 62 & $78(5)$ & $58(7)$ & $48(7)$ & $35(7)$ & $32(7)$ & \\
\hline \multicolumn{8}{|l|}{ Site } \\
\hline Alveolus & 101 & $81(4)$ & $63(5)$ & $53(5)$ & $48(6)$ & $45(6)$ & 0.31 \\
\hline Hard palate & 35 & $83(6)$ & $71(8)$ & $68(8)$ & $55(9)$ & $47(9)$ & \\
\hline Max sinus & 34 & $76(7)$ & $63(9)$ & $59(9)$ & $39(10)$ & $32(10)$ & \\
\hline Nasal & 13 & 49 (17) & 49 (17) & $49(17)$ & $33(18)$ & $17(15)$ & \\
\hline \multicolumn{8}{|l|}{ Overall P stage } \\
\hline Early (1-2) & 38 & $97(3)$ & $81(7)$ & $71(8)$ & $59(9)$ & $59(9)$ & 0.007 \\
\hline Later (3-4) & 132 & $73(4)$ & $56(5)$ & $51(5)$ & $41(5)$ & $36(5)$ & \\
\hline \multicolumn{8}{|l|}{ Diagnosis } \\
\hline $\mathrm{SCC}$ & 158 & $79(3)$ & $62(4)$ & $54(4)$ & $44(4)$ & $40(4)$ & 0.63 \\
\hline No SCC & 25 & $75(9)$ & $70(10)$ & $65(10)$ & $58(11)$ & $52(12)$ & \\
\hline \multicolumn{8}{|l|}{ Browns classification } \\
\hline Low (1-2) & 142 & $78(4)$ & $62(4)$ & $53(5)$ & $46(5)$ & $41(5)$ & 0.67 \\
\hline High (3-4) & 41 & $83(6)$ & $70(7)$ & $64(8)$ & $47(8)$ & $44(8)$ & \\
\hline \multicolumn{8}{|l|}{ ASA } \\
\hline 1 & 37 & $87(6)$ & $56(9)$ & $52(9)$ & $36(9)$ & $36(9)$ & 0.97 \\
\hline 2 & 103 & $76(4)$ & $67(5)$ & $57(5)$ & $49(5)$ & $43(6)$ & \\
\hline $3-4$ & 36 & $78(7)$ & $62(9)$ & $58(9)$ & $44(10)$ & $39(10)$ & \\
\hline \multicolumn{8}{|l|}{ Treatment } \\
\hline Surgery $(\mathrm{S})$ alone & 73 & $84(4)$ & $73(5)$ & $67(6)$ & $59(6)$ & $53(7)$ & 0.02 \\
\hline $\mathrm{S}$ and (RT or CT or RTCT) & 110 & $75(4)$ & $57(5)$ & $49(5)$ & $37(5)$ & $34(5)$ & \\
\hline \multicolumn{8}{|l|}{ Flap } \\
\hline No & 42 & $85(6)$ & $80(6)$ & $69(7)$ & $57(8)$ & $51(8)$ & $0.18 * *$ \\
\hline Soft & 81 & $77(5)$ & $60(6)$ & $55(6)$ & $43(6)$ & $41(6)$ & \\
\hline Composite & 60 & $77(6)$ & $56(7)$ & $49(7)$ & $42(7)$ & $37(7)$ & \\
\hline \multicolumn{8}{|l|}{ LOS (days) } \\
\hline$\leq 7$ & 53 & $89(4)$ & $79(6)$ & $70(7)$ & $57(8)$ & $53(9)$ & 0.004 \\
\hline $8-14$ & 63 & $71(6)$ & $64(6)$ & $53(7)$ & $41(7)$ & $38(7)$ & \\
\hline$\geq 15$ & 52 & $77(6)$ & $47(7)$ & $44(7)$ & $35(7)$ & $32(7)$ & \\
\hline \multicolumn{8}{|l|}{ Rehabilitation (Prostheses) } \\
\hline None provided & 75 & $70(5)$ & $47(6)$ & $41(6)$ & $26(6)$ & $26(6)$ & 0.001 \\
\hline Non-implant & 39 & $87(5)$ & $71(7)$ & $62(8)$ & $52(9)$ & $45(9)$ & \\
\hline Implant & 65 & $83(5)$ & $80(5)$ & $72(6)$ & $70(7)$ & $62(8)$ & \\
\hline
\end{tabular}

$R T$ radiotherapy, $C T$ chemotherapy, $N A$ not applicable

*Log-rank test, excluding NK (not known) where applicable

$* * P=0.07$ for flap (soft or composite) vs no flap 


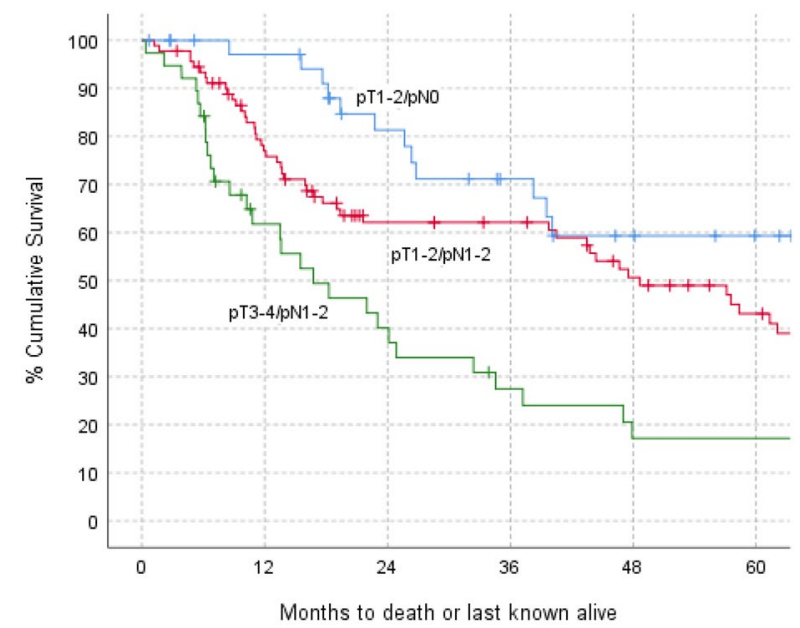

Log-rank test: Chi-squared $=19.30,2 \mathrm{df}, \mathrm{p}<0.001$

Fig. 1 Kaplan-Meier survival by pTN stage. Log-rank test: Chisquared $=19.30,2 \mathrm{df}, P<0.001$

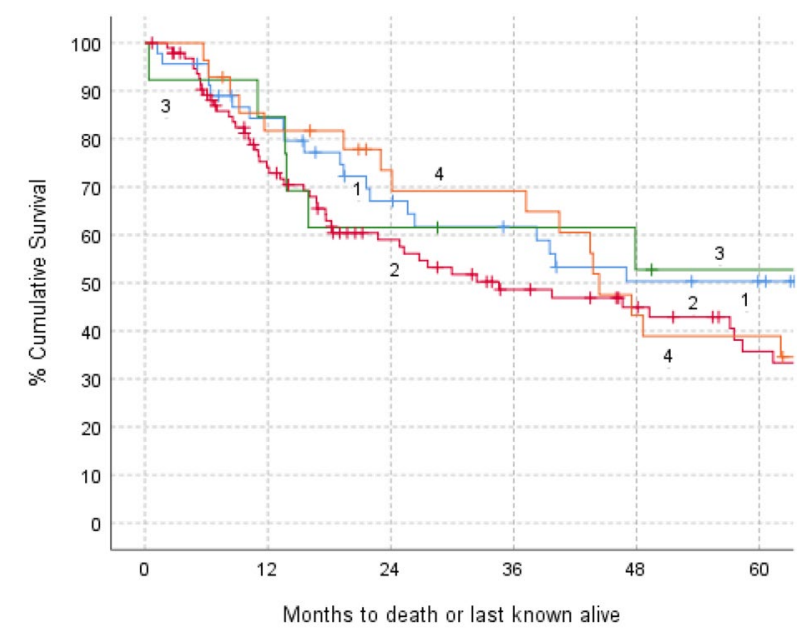

Log-rank test: Chi-squared $=2.70,2 \mathrm{df}, \mathrm{p}=0.44$

Fig. 2 Kaplan-Meier survival by Browns classification (1-4). Logrank test: Chi-squared $=2.70,2 \mathrm{df}, P=0.44$

Acknowledgements Other consultants if not co-authors

Funding This study was unfunded.

\section{Declarations}

The study complied with all aspects of ethical standards of clinical research.

Conflict of interest We do not have financial disclosure or any conflict of interest.
Ethical approval The data were collected as part of the clinical audit process and this study was approved by Liverpool University Hospital NHS Foundation Trust Audit Department (CAMS reference 10074).

Informed consent The data were collected as part of routine clinical care, anonymised, collated, and analysed, and thus no individual patient consent was sought.

Open Access This article is licensed under a Creative Commons Attribution 4.0 International License, which permits use, sharing, adaptation, distribution and reproduction in any medium or format, as long as you give appropriate credit to the original author(s) and the source, provide a link to the Creative Commons licence, and indicate if changes were made. The images or other third party material in this article are included in the article's Creative Commons licence, unless indicated otherwise in a credit line to the material. If material is not included in the article's Creative Commons licence and your intended use is not permitted by statutory regulation or exceeds the permitted use, you will need to obtain permission directly from the copyright holder. To view a copy of this licence, visit http://creativecommons.org/licenses/by/4.0/.

\section{References}

1. Triana RJ Jr, Uglesic V, Virag M, Varga SG, Knezevic P, Milenovic A, Aljinovic N, Murakami CS, Futran ND (2000) Microvascular free flap reconstructive options in patients with partial and total maxillectomy defects. Arch Facial Plast Surg 2(2):91-101. https://doi.org/10.1001/archfaci.2.2.91

2. Mücke T, Hölzle F, Loeffelbein DJ, Ljubic A, Kesting M, Wolff KD, Mitchell DA (2011) Maxillary reconstruction using microvascular free flaps. Oral Surg Oral Med Oral Pathol Oral Radiol Endod 111(1):51-57. https://doi.org/10.1016/j.tripleo.2010.03. 042 (Epub 2010 Jun 29)

3. Brown JS, Rogers SN, McNally DN, Boyle M (2000) A modified classification for the maxillectomy defect. Head Neck 22(1):17-26. https://doi.org/10.1002/(sici)1097-0347(200001) 22:1\%3c17::aid-hed4\%3e3.0.co;2-2

4. Cordeiro PG, Santamaria E (2000) A classification system and algorithm for reconstruction of maxillectomy and midfacial defects. Plast Reconstr Surg 105(7):2331-2346. https://doi.org/ 10.1097/00006534-200006000-00004

5. Okay DJ, Genden E, Buchbinder D, Urken M (2001) Prosthodontic guidelines for surgical reconstruction of the maxilla: a classification system of defects. J Prosthet Dent 86(4):352-363. https://doi.org/10.1067/mpr.2001.119524

6. Santamaria E, Cordeiro PG (2006) Reconstruction of maxillectomy and midfacial defects with free tissue transfer. J Surg Oncol 94(6):522-531. https://doi.org/10.1002/jso.20490

7. Brown JS, Shaw RJ (2010) Reconstruction of the maxilla and midface: introducing a new classification. Lancet Oncol 11(10):10011008. https://doi.org/10.1016/S1470-2045(10)70113-3

8. Bidra AS, Jacob RF, Taylor TD (2012) Classification of maxillectomy defects: a systematic review and criteria necessary for a universal description. J Prosthet Dent 107(4):261-270. https://doi. org/10.1016/S0022-3913(12)60071-7

9. Akinmoladun VI, Dosumu OO, Olusanya AA, Ikusika OF (2013) Maxillectomy defects: a suggested classification scheme. Afr J Med Med Sci 42(2):171-175

10. Boyes-Varley JG, Howes DG, Davidge-Pitts KD, Brånemark I, McAlpine JA (2007) A protocol for maxillary reconstruction 
following oncology resection using zygomatic implants. Int $\mathbf{J}$ Prosthodont 20(5):521-531

11. Dalgorf D, Higgins K (2008) Reconstruction of the midface and maxilla. Curr Opin Otolaryngol Head Neck Surg 16(4):303-311. https://doi.org/10.1097/MOO.0b013e328304b426

12. Cordeiro PG, Chen CM (2012) A 15-year review of midface reconstruction after total and subtotal maxillectomy: part I. Algorithm and outcomes. Plast Reconstr Surg 129(1):124-136. https:// doi.org/10.1097/PRS.0b013e318221dca4

13. Hanasono MM, Silva AK, Yu P, Skoracki RJ (2013) A comprehensive algorithm for oncologic maxillary reconstruction. Plast Reconstr Surg 131(1):47-60. https://doi.org/10.1097/PRS.0b013 e3182729e73

14. Costa H, Zenha H, Sequeira H, Coelho G, Gomes N, Pinto C, Martins J, Santos D, Andresen C (2015) Microsurgical reconstruction of the maxilla: algorithm and concepts. J Plast Reconstr Aesthet Surg 68(5):e89-e104. https://doi.org/10.1016/j.bjps.2014. 12.002 (Epub 2015 Jan 14)

15. Eskander A, Kang SY, Teknos TN, Old MO (2017) Advances in midface reconstruction: beyond the reconstructive ladder. Curr Opin Otolaryngol Head Neck Surg 25(5):422-430. https://doi. org/10.1097/MOO.0000000000000396

16. Rogers SN, Brown JS, Woolgar JA, Lowe D, Magennis P, Shaw RJ, Sutton D, Errington D, Vaughan D (2009) Survival following primary surgery for oral cancer. Oral Oncol 45(3):201-211. https://doi.org/10.1016/j.oraloncology.2008.05.008 (Epub 2008 Jul 31)

17. Sun Q, Zhang WB, Gao M, Yu S, Mao C, Guo CB, Yu GY, Peng $X$ (2020) Does the Brown classification of maxillectomy defects have prognostic prediction for patients with oral cavity squamous cell carcinoma involving the maxilla? Int J Oral Maxillofac Surg 49(9):1135-1142. https://doi.org/10.1016/j.ijom.2020.01.021 (Epub 2020 Feb 17)

18. Dos-Santos DM, de-Caxias FP, Bitencourt SB, Turcio KH, Pesqueira AA, Goiato MC (2018) Oral rehabilitation of patients after maxillectomy. A systematic review. Br J Oral Maxillofac Surg 56(4):256-266. https://doi.org/10.1016/j.bjoms.2018.03.001 (Epub 2018 Apr 11)

19. Petrides GA, Hicks G, Dunn M, Froggatt C, Wallace C, Howes D, Leinkram D, Low TH, Ch'ng S, Wykes J, Palme CE, Clark JR (2021) Dentoalveolar outcomes in maxillary reconstruction: a retrospective review of 85 maxillectomy reconstructions. ANZ J Surg 91(7-8):1472-1479. https://doi.org/10.1111/ans.17001 (Epub 2021 Jun 14)

20. National Clinical Coding Standards OPCS-4 (2017) Copyright $(C$ 2017 health and social care information centre. In: The health and social care information centre is a non-departmental body created by statute, also known as NHS Digital. http://systems.digital.nhs. uk/data/clinicalcoding

21. Rogers SN, Lowe D, McNally D, Brown JS, Vaughan ED (2003) Health-related quality of life after maxillectomy: a comparison between prosthetic obturation and free flap. J Oral Maxillofac Surg 61(2):174-181. https://doi.org/10.1053/joms.2003.50044

22. Brown JS, Bekiroglu F, Shaw RJ, Woolgar JA, Triantafyllou A, Rogers SN (2013) First report of elective selective neck dissection in the management of squamous cell carcinoma of the maxillary sinus. Br J Oral Maxillofac Surg 51(2):103-107. https://doi.org/ 10.1016/j.bjoms.2012.04.004 (Epub 2012 May 11)

23. Mayhew D, Mendonca V, Murthy BVS (2019) A review of ASA physical status-historical perspectives and modern developments. Anaesthesia 74(3):373-379. https://doi.org/10.1111/anae. 14569 (Epub 2019 Jan 15)

24. Lydiatt WM, Patel SG, Osullivan B, Brandwein MS, Ridge JA, Migliacci JC, Loomis AM, Shah JP (2017) Head and Neck cancers-major changes in the American Joint Committee on cancer eighth edition cancer staging manual. CA Cancer J Clin
67(2):122-137. https://doi.org/10.3322/caac.21389 (Epub 2017 Jan 27)

25. (2021) http://www.handle-on-qol.com/Index.aspx. Accessed 24 Dec 21

26. Kanatas A, Ghazali N, Lowe D, Udberg M, Heseltine J, O'Mahony E, Rogers SN (2013) Issues patients would like to discuss at their review consultation: variation by early and late stage oral, oropharyngeal and laryngeal subsites. Eur Arch Otorhinolaryngol 270(3):1067-1074. https://doi.org/10.1007/s00405-012-2092-6 (Epub 2012 Jun 29)

27. Pace-Balzan A, Butterworth C, Lowe D, Rogers SN (2009) The responsiveness of the Liverpool oral rehabilitation questionnaire (LORQ): a pilot study. Int J Prosthodont 22(5):456-458

28. Hughes C, Homer J, Bradley P, Nutting C, Ness A, Persson M, Jeffreys M, Waylen A, Leary S, Thomas S (2012) An evaluation of current services available for people diagnosed with head and neck cancer in the UK (2009-2010). Clin Oncol (R Coll Radiol) 24(10):e187-e192. https://doi.org/10.1016/j.clon.2012.07.005 (Epub 2012 Jul 31)

29. Chrcanovic BR, Abreu MH (2013) Survival and complications of zygomatic implants: a systematic review. Oral Maxillofac Surg 17(2):81-93. https://doi.org/10.1007/s10006-012-0331-z (Epub 2012 May 6)

30. Huang W, Wu Y, Zou D, Zhang Z, Zhang C, Sun J, Xu B, Zhang Z (2014) Long-term results for maxillary rehabilitation with dental implants after tumor resection. Clin Implant Dent Relat Res 16(2):282-291. https://doi.org/10.1111/j.1708-8208.2012.00481.x (Epub 2012 Aug 9)

31. Butterworth CJ, Rogers SN (2017) The zygomatic implant perforated (ZIP) flap: a new technique for combined surgical reconstruction and rapid fixed dental rehabilitation following low-level maxillectomy. Int J Implant Dent. 3(1):37. https://doi.org/10.1186/ s40729-017-0100-8 (Epub 2017 Jul 29)

32. Hackett S, El-Wazani B, Butterworth C (2021) Zygomatic implant-based rehabilitation for patients with maxillary and midfacial oncology defects: a review. Oral Dis 27(1):27-41. https:// doi.org/10.1111/odi.13305 (Epub 2020 Mar 5)

33. Butterworth CJ, Lowe D, Rogers SN (2021) The Zygomatic Implant Perforated (ZIP) flap reconstructive technique for the management of low-level maxillary malignancy-clinical \& patient related outcomes on 35 consecutively treated patients. Head Neck. https://doi.org/10.1002/hed.26933

34. Bhattacharyya $\mathrm{N}$ (2003) Factors affecting survival in maxillary sinus cancer. J Oral Maxillofac Surg 61(9):1016-1021. https:// doi.org/10.1016/s0278-2391(03)00313-6

35. Lin HW, Bhattacharyya N (2009) Survival impact of nodal disease in hard palate and maxillary alveolus cancer. Laryngoscope 119(2):312-315. https://doi.org/10.1002/lary.20054

36. Hakim SG, Steller D, Sieg P, Rades D, Alsharif U (2020) Clinical course and survival in patients with squamous cell carcinoma of the maxillary alveolus and hard palate: results from a single-center prospective cohort. J Craniomaxillofac Surg 48(1):111-116. https://doi.org/10.1016/j.jcms.2019.12.008 (Epub 2019 Dec 13)

37. Rude K, Thygesen TH, Sørensen JA (2014) Reconstruction of the maxilla using a fibula graft and virtual planning techniques. BMJ Case Rep 2014:bcr2014203601. https://doi.org/10.1136/ bcr-2014-203601

38. Seikaly H, Idris S, Chuka R, Jeffery C, Dzioba A, Makki F, Logan H, O'Connell DA, Harris J, Ansari K, Biron V, Cote D, Osswald M, Nayar S, Wolfaardt J (2019) The alberta reconstructive technique: an occlusion-driven and digitally based jaw reconstruction. Laryngoscope 129(Suppl 4):S1-S14. https://doi.org/10.1002/lary. 28064 (Epub 2019 Jun 26)

39. Tamaki A, Seim NB, Valentin S, Ozer E, Agrawal A, VanPutten M, Kang SY, Old MO (2020) The use of medical modeling in microvascular free tissue transfer reconstruction with 
osseointegrated implantation in complex midface defects. Oral Oncol 110:104982. https://doi.org/10.1016/j.oraloncology.2020. 104982 (Epub 2020 Sep 23)
Publisher's Note Springer Nature remains neutral with regard to jurisdictional claims in published maps and institutional affiliations. 